\title{
The Effect of Task Repetition on Fluency And Accuracy of EFL Saudi Female Learners' Oral Performance
}

\author{
Amani K. Gashan (Corresponding author) \\ College of Education, King Saud University, Saudi Arabia \\ E-mail address: ebra1982@hotmail.com \\ Fahad M. Almohaisen \\ College of Education, King Saud University, Saudi Arabia
}

Doi:10.7575/aiac.alls.v.5n.3p.36

Received: 06/04/2014

URL: http://dx.doi.org/10.7575/aiac.alls.v.5n.3p.36

Accepted: 09/05/2014

\begin{abstract}
This study aimed to examine the effect of task repetition on foreign language output. Twenty eight Saudi female students in the Preparatory Year (PY) at King Saud university, were randomly selected to conduct an oral informationgap task. The participants were asked to perform the task two times with two-week interval between the two performances. The oral performances were transcribed and analyzed to measure fluency and accuracy of language output. The collected data were coded for the two dimensions of oral production (fluency and accuracy), based on the established criteria. A within group dependent t-test for paired samples was computed to find out whether there were significant differences between the mean scores of the first and the second performances. The findings revealed that task repetition resulted in significant differences in the subjects' oral discourse in terms of fluency and accuracy. The findings of the current study recommend that researchers and teachers might find it very beneficial to devote some of their time to design effective task repetition to help language learners improve their oral production.
\end{abstract}

Keywords: task repetition, language output, accuracy, fluency

\section{Introduction}

Recently, there are many calls for a move in language teaching toward task-based approaches to instruction (Ellis, 2003). Language learning could be improved through offering opportunities for learners to engage in task performance which could be seen as rehearsal for interaction to come. Focusing on oral tasks as pedagogic tools might open up wider perspectives for enhancing language learning. It is assumed that while language learners get involved in performing the tasks, they naturally engage in certain kinds of language use and mental processing that are very beneficial for language acquisition.

Ellis (2003) argued that tasks could be used in language teaching classes to reduce the cognitive or linguistic demands placed on the language learner. However, the trade-off assumption suggested that "language learners have available limited attention capacities, that the different components of language production and comprehension compete with each other for such limited capacities, and that the choice to devote attention to one specific side may will be at the expense of other sides" (Ellis, 2005). Thus, through the manipulation of the language learners' attention to focus on linguistic forms has become a key priority in research. The exploration of this field could result in better understanding of how attention could be directed toward various language components, and in turn better language acquisition.

Ellis (2005) distinguished between two main kinds of task-based planning, namely pre-task planning and within-task planning. Pre-task planning is then divided into rehearsal (or repetition) and strategic planning. Repetition involves conducting a task before the main performance with the first performance of that task is regarded as a kind of preparation for the next task performance (Ellis, 2005). When language learners are required to perform an oral task, which is by its nature meaning-focused and outcome-oriented, this naturally induces them to deal with what they plan to say first "conceptualization" (Skehan, 2009). During their first task performance, the speakers are mainly concerned with the preparation of the preverbal message, consequently, they pay only little attention to lexico-grammatical selection which naturally takes place during the stage of formulation. However, when the speaker is offered an opportunity to repeat the task, a considerable part of the conceptualizing, formulating and articulating process has already been conducted in the first task performance (Bygate \& Samuda, 2005), and as a result, attentional resources are freed up to be allocated to various dimensions of oral output. This may lead to an enhancement of the speaker's language production of the same meanings expressed in the first performance of the task. Bygate (2001) stated that task repetition is particularly beneficial to enhance task performer's fluency. Probably because when they already know what they will say in their task performance, they have more processing space available to be used in the formulating stage of the language required to express their thoughts, with the result that the amount of the output will be enhanced (Ellis, 2003). 
Some of second language acquisition (SLA) researchers consider repetition as mainly a kind of planning which is promising to channel second language learners' limited attentional resources (Ahmadian \& Tavakoli, 2011; Bygate, 2006; Ellis, 2005, 2008, 2009; Bygate \& Samuda, 2005; Skehan, 2007). Bygate (2001) stated that the theoretical logic behind the assumption that repeating the oral task can assist oral language production, is based on the point that part of the work of conceptualization, formulation and articulation processed on the first performance is kept in the memory store of the speakers, which in turn could be retrieved on the second performance. During the initial oral performance of the task, language learners are primarily concerned with the planning of content of what they are going to say (Bygate, 2001). Language learners can scan their memory store for the language that best suits the performance of the oral task and consequently they start to be familiar with the content to be produced. On the second performance of the task and due to the fact that language learners are already familiar with the content, they have ample time and attentional resources to shift their attention from content to the process of selecting and editing the suitable language, which in turn could result in enhanced language output (Bygate, 2001). However, Ellis (2009) suggested that there is no clear evidence that task repetition assists acquisition.

One of the earliest studies in task repetition is Lynch \& McLean's (2001) study which was conducted in English for Specific Purposes (ESP) context. In this study fourteen English language learners performed a poster-carousel task that required the participants to respond repeatedly to the same or similar questions from fellow students about a poster they had prepared. Lynch and McLean concluded that task repetition would benefit both linguistic accuracy and fluency. In another study by Bygate (2001), the researcher compared the performances of forty eight ESL learners on narrative and interview tasks, on two occasions with a 10 -week interval in between. The researcher found that repeating the task resulted in a significant effect on the fluency of learners' performances. However, Bygate reported no statistically significant effect on his study's general measurements of accuracy.

Sheppard (2006) explored the effects of repeating the oral task accompanied by feedback on accuracy and fluency. The researcher provided feedback in order to to draw performers' attention to the linguistic form between the first performance and the second one. Sheppard's study indicated that repeating the oral task provided by suitable feedback clearly enhanced the fluency and accuracy of language performance. Taguchi (2008) investigated the enhancement of language fluency in spoken production among second language learners who performed repeated practice of grammatical features as constituent units of discourse. The participants of this study were twenty two language learners enrolled in an elementary Japanese course at a university in the US. They were taught forty grammatical features through the use of communicative drills and memorization of dialogues containing specific features. The performers completed two conversation tasks in Japanese with five week intervals between them. Taguchi found no significant enhancement in fluency of their oral output. The researcher explained that as the beginning-level participants learned a great deal of linguistic expressions, as a consequent it took them some time to survey a range of these expressions and choose the most appropriate ones which might lead to slower overall speaking process.

In another hand, Hawkes (2012) found that task repetition could be used as a pedagogic tool to direct second language learners' attention towards the forms of the language. In a more recent study in task repetition, Ahmadian \& Tavakoli (2011) investigated the effects of the simultaneous use of task repetition on oral output. This study showed that repeating the oral task simultaneously would enhance fluency and accuracy together. Takimoto (2012) explored the effectiveness of two types of repetition when teaching polite request forms to Japanese English as a second language learners: the task-type repetition and the identical task repetition. The results implied that identical task repetition was more effective than task-type repetition in learners' production of second language.

Reviewing the previous studies in task repetition, it could be conclude that most of the conducted studies found positive effect of repetition on language production (Lynch \& McLean, 2001; Sheppard, 2006; Ahmadian \& Tavakoli, 2011). However, some studies failed to find significant enhancement on either language production dimensions (Bygate, 2001; Taguchi, 2008). The effects of task repetition condition on the fluency, and accuracy of oral task production are thus still open to question. The simultaneous use of task repetition was found to advantage both fluency and accuracy (Tavakoli \& Skehan, 2005), while longer intervals i.e., 10-week interval as in Bygate (2001), and 5-week interval as in Taguchi (2008), failed to find improvement on fluency or accuracy of language output. Thus, the current study will further explore the effect of repeating the task with a two-week interval in between. Also, as far as the researcher knows, there was no study conducted to explore the effect of oral task repetition with information- gap task type. In order to address this limitation in the previous studies, the current study intended to explore the effect of planning with the informationgap activity. Furthermore, to the best of the present researcher's knowledge, no study to date has explored the effect of task repetition on the performance of EFL learners in Arabic context. Thus, the aim of the present study was to develop a greater understanding of the influence of task repetition on the accuracy, and fluency of foreign language oral productions, among a population of Arabic-speaking learners of English. In this current study, the researchers investigated if there is evidence of language production enhancement when the need to focus on meaning has been minimized through task repetition, thereby freeing learners to attend to form.

\section{Research Questions}

1. Does repeating the same task lead to improvement in EFL oral task performance?

1.1 Does task repetition increase fluency of EFL learners' oral production?

1.2 Does task repetition increase accuracy of EFL learners' oral production? 


\section{Methodology}

\subsection{Participants}

This study was conducted with twenty eight Saudi female post-beginner level students in the Preparatory Year at King Saud University. They were selected and assigned into pairs using a simple random selection. Most of them had been learning English as a foreign language in Saudi schools for six years. Their mother tongue is Arabic. None had ever been to an English-speaking country, and they had had little opportunity to use English for communicative purposes outside the classroom (Rahman \& Alhaisoni, 2013). They were between 19 and 22 years old at the time of data collection.

\subsection{Materials}

For the purpose of the present study, a task about spotting the differences between two pictures (information-gap), was adopted as the input material. The task was developed by Alshumaimeri (2010). It was piloted and tested by Alshumaimeri to check its validity and reliability to suite Saudi post-beginner students. It was a task with two-way, information-gap activity. The participants were required to exchange information about ten differences between two versions of a picture. The language included common vocabulary related to the task. (see appendix)

\subsection{Procedure}

Before performing the task, the participants were instructed about the specific task and were told what they were supposed to do. The participants were required to work in pairs. Every pair was asked to do the task. Learners were given two versions of a picture and asked to find out the differences in the two pictures. The participants had no exposure to the task before. The participants hadn't been informed in advance about the repetition of the task in order to diminish the practice effect. They were asked to perform the task for the first time, and they were instructed not to look at the other one's picture during the practice. After an interval time of two weeks, the participants were asked to repeat the same task but this time the researcher changed the roles of the participants. The conversations were recorded using an MP3 recorder. The first 1.20 minutes of the conversations were transcribed and analyzed in terms of accuracy and fluency.

\subsection{Data Coding}

The audiotaped data was then transcribed and coded to assess the fluency, and accuracy of the learners' oral language output.

\subsubsection{Fluency}

Fluency has been defined as "the production of language in real time without undue pausing or hesitation" (Ellis \& Barkhuizen, 2005). It could be defined also as "the extent to which the language produced in performing a task manifests pausing, hesitation, or reformulations" (Ellis, 2003). Following Foster \& Skehan, 1996; Skehan \& Foster, 1999; Elder \& Iwashita, 2005, fluency was measured by counting "the number of repetitions (of the same word or phrase), false starts (utterances abandoned before completion), reformulations (phrases or clauses repeated with some modification to syntax, morphology, or word order) and replacements (substitution of one lexical item for another)".

\subsubsection{Accuracy}

Accuracy is defined as "the ability to produce error-free speech" (Housen \& Kuiken, 2009). Ellis (2005) stated that accuracy can be defined as "the ability of the speaker to avoid errors in performance, possibly reflecting higher levels of control in the language as well as a conservative orientation". In the current study, accuracy was measured by calculating the number of error-free clauses. All errors in syntax, morphology, and lexical choice were counted. High means indicate less number of errors and as a result better performance. The same measure has been used in some previous studies (e.g., Yuan \& Ellis, 2003; Guará -Tavares, 2008).

\section{Results}

To answer the research questions, a within group dependent t-test for paired samples was computed to find out whether there were significant differences in language performance between the mean scores of the first and the second performances.

Table 1. Shows the t-test and mean scores of the accuracy for the first performance and the repetition.

\begin{tabular}{llllll}
\hline Accuracy & Performance & Mean & Std. Deviation & t-Value & Sig. (Two-Tailed) \\
\hline Error-free clauses & First & 6.428 & 2.026 & 7.558 & 0.00 \\
& Second & 24.50 & 1.789 & & \\
\hline
\end{tabular}

Table 1 shows that during the first performance, the accuracy mean score of the participating speakers was (6.428), whereas during the second performance, it clearly increased and became (24.50). A statically significant difference between the first performance and the repetition scores was found at the $\mathrm{p}<.05$ level $[\mathrm{T}=7.558), \mathrm{p}=0.00]$. This means that accuracy was significantly improved as a result of the repetition. Students committed fewer errors in the second oral task performance. 
Table 2. Shows the t-test and mean scores of the fluency for the first performance and the repetition.

\begin{tabular}{llllll}
\hline Fluency & Performance & Mean & Std. Deviation & t-Value & Sig. (Two-Tailed) \\
\hline Repetitions & First & 13.821 & 3.972 & 8.023 & 0.00 \\
& Second & 10.357 & 3.703 & & \\
False starts & First & 12.964 & 3.132 & 4.825 & 0.00 \\
& Second & 10.785 & 3.107 & & \\
Reformulations & First & 9.285 & 3.309 & 2.187 & 0.038 \\
& Second & 8.285 & 2.929 & & \\
Replacements & First & 7.178 & 2.553 & \multirow{2}{*}{3.932} & 0.001 \\
& Second & 5.250 & 2.757 & & \\
\hline Total & First & 43.25 & 8.094 & 8.890 & 0.00 \\
& Second & 34.678 & 7.092 & & \\
\hline
\end{tabular}

The mean scores for fluency in table 2 tells us that the participants showed better performance in the second performance $(M=34.678)$ than in the first one $(M=43.25)$ in terms of the total fluency measurements. The enhancement was statistically significant at the $\mathrm{p}<.05$ level $[\mathrm{T}=8.890), \mathrm{p}=0.00]$ in the total measurements. It means that performing the same oral task for the second time with the time interval of two weeks had a significant effect on the participants' fluency.

\section{Discussion}

The present study focused on the impact of repeating oral task on fluency and accuracy of language performance. The results showed some evidence that task repetition resulted in improvement in language learners' oral performance. The current study is consistent with some previous studies (Lynch \& Maclean, 2001; Sheppard, 2006; Ahmadian \& Tavakoli, 2011) that found support for the beneficial effect of repetition on accuracy. This study also supports the previous studies (Bygate, 2001; Lynch \& Maclean, 2001; Ahmadian \& Tavakoli, 2011) that found repetition to be beneficial with the fluency of oral performance.

Repeating the oral task performance was found to assist foreign language learners with low level of proficiency who primarily do not have ready-made plans to facilitate their language production under real time. In the first performance, language learners would be concerned with planning the content of the message to produce. On the second performance, they would be more concerned with paying attention to the formulation aspect of the task. Bygate and Samuda (2005) stated that at the first encounter, the language learners are supposed to rely on the most automated aspects of their language, than at the second one. In contrast, at the second encounter, they are not only cognitively prepared, but furthermore, their vocabulary and grammar are primed, so that there is a chance on the second task performance that the language learner would be able to generate more accurate and fluent output.

The results of the present study suggested that the experience of the first performance of the task would be available for the speakers to build on in the second performance, which in turn may lead to more accurate and fluent language production. It could be argued that oral performance can be more fluent and accurate due to the fact that doing the task a second time would involve less planning work. Also because the task has already been formulated previously, we can expect fewer false starts and self-corrections.

\section{Conclusion}

The present study tried to cast some light on the effect of task repletion on the accuracy and fluency of foreign language oral performance. The findings of the present study came to conclude that when EFL learners are asked to repeat the information-gap task, they likely to get some improvements in their accuracy and fluency. It also supported Bygate's (2001) claim that in the first task performance, language learners can familiarize themselves with the content to be produced, and later in the second performance of the task, they have ample attentional resources to focus on the selecting and editing of the appropriate language, which in turn might result in better language output. Task repetition can play a critical role in providing the language learners with in-built planning opportunity. It also could provide a beneficial context for students and teachers to plan their subsequent language work. Repetition could be seen as a task performance condition that could be used to manipulate the learners' attention through freeing up processing resource capacities. Further research is needed to investigate the effects of identical task repetition and task-type repetition on the complexity of EFL oral language performance. The current study contributed to our understanding of the effectiveness of task repetition in the acquisition of foreign language in two important ways: First, identical task repetition is effective in promoting gains in enhancing the oral production through enabling language learners to perform tasks more fluently. Second, more effective learning occurs with identical task repetition, which seems to reinforce the accuracy of language learners. Thus, one implication of the current study is that researchers and teachers might find it very beneficial to devote some of their time to the designing of the effective task repetition to help their language learners improve their oral production. 


\section{Acknowledgments}

The authors would like to extend their appreciation to the College of Education Research Center, Deanship of Scientific Research, King Saud University, for funding this research work. They also would like to express sincere gratitude to Prof. Dr. Yousif A. Alshumaimeri for his guidance, efforts, advice, assistance and unremitting support in helping them to complete this study.

\section{References}

Ahmadian, M., \& Tavakoli, M. (2011). The effects of simultaneous use of careful online planning and task repetition on accuracy, complexity, and fluency in EFL learners' oral production. Language Teaching Research, 15(1),35-59.

Alshumaimeri, Y. (2010). Using oral pedagogic tasks with learners of English in Saudi Arabia: Motivation and oral performance. Saarbrücken: Lambert Academic Publishing.

Bygate, M. (2001). Effects of task repetition on the structure and control of oral language. In M. Bygate, P. Skehan, \& M. Swain (Eds.), Researching pedagogic tasks: Second language learning, teaching and testing (pp. 23-48). Harlow, UK: Longman.

Bygate, M. (2006). Areas of research that influence L2 speaking instruction. In Uso-Juan, E., \& Martinez-Flor, A. (Eds.), Current trends in the development and teaching of the four language skills. (pp. 159-186). Berlin: Mouton de Gruyter.

Bygate, M. \& Samuda, V. (2005). Integrative planning through the use of task repetition. In R. Ellis (Ed.), Planning and task performance in a second language (pp. 37-74). Amsterdam/Philadelphia: John Benjamins.

Elder, C., \& Iwashita, N. (2005). Planning for test performance: Does it make a difference? In R. Ellis (Ed.), Planning and task performance in a second language (pp. 219-238). Amsterdam/Philadelphia: John Benjamins.

Ellis, R. (2003). Task-based language learning and teaching. Oxford: Oxford University Press.

Ellis, R. (2005). Planning and task-based performance: Theory and research. In R. Ellis (Ed.), Planning and task performance in a second language (pp. 3-36). John Benjamins.

Ellis, R. (2008). The study of second language acquisition. Oxford: Oxford University Press.

Ellis, R., (2009). The differential effects of three types of task planning on the fluency, complexity, and accuracy in L2 oral production. Applied Linguistics, 30(4), 474-509.

Ellis, R., \& Barkhuizen, G. (2005). Analysing learner language. New York: Oxford University Press.

Foster, R., \& Skehan, P. (1996). The influence of planning and task type on second language performance. Studies in Second Language Acquisition, 18, 299-323.

Guará-Tavares, M. (2008). Pre-task planning, working memory capacity and L2 speech performance. (Unpublished doctoral dissertation). Universidade Federal de Santa Catarina, Florianópolis, Brazil.

Hawkes, M. (2012). Using task repetition to direct learner attention and focus on form. ELT Journal, 66(3), 327-336.

Housen, A., \& Kuiken, F.(2009). Complexity, accuracy, and fluency in second language acquisition. Applied Linguistics, 30(4), 461-473.

Lynch, T., \& Maclean, J. (2001). Effects of immediate task repetition on learners' performance. In M. Bygate, P. Skehan, \& M. Swain (Eds.), Researching pedagogic tasks: Second language learning, teaching and testing (pp. 141162). Harlow, UK: Longman.

Rahman, M., \& Alhaisoni, E. (2013). Teaching English in Saudi Arabia: Prospects and challenges. Academic Research International, 4(1), 112-118.

Sheppard, C. (2006). The effects of instruction directed at the gaps second language learners noticed in their oral production. Unpublished PhD thesis, University of Auckland, New Zealand. In Ellis, R. (2009). 'The differential effects of three types of task planning on the fluency, complexity and accuracy in L2 oral production'. Applied Linguistics, 30(4), 474-509.

Skehan P. (2007). Task research and language teaching: Reciprocal relationships. In S. Fotos (Eds.), Form-meaning relationships in language pedagogy: Essays in honour of Rod Ellis (PP. 55-69). Oxford: Oxford University Press.

Skehan, P. (2009). Modeling second language performance: integrating complexity, accuracy, fluency, and lexis. Applied Linguistics, 30(4), 510-32.

Skehan, P., \& Foster, P. (1999). The influence of task structure and processing conditions on narrative retellings. Language Learning, 49, 93-120.

Taguchi, N. (2008). Building language blocks in L2 Japanese: Chunk learning and the development of complexity and fluency in spoken production. Foreign Language Annals, 41(1), 132-156.

Takimoto M. (2012). Assessing the effects of identical task repetition and task-type repetition on learners' recognition and production of second language request downgraders. Intercultural Pragmatics, 9 (1),71 - 96.

Yuan, F., \& Ellis, R. (2003). The effects of pre-task planning and on-line planning on fluency, complexity and accuracy in L2 monologic oral production. Applied Linguistics, 24(1), 1-27. 
Appendix : Information-gap task ( Spot the differences)

\section{Student Handout : Spot the difference!}

Work in pairs. You are trying to find 10 differences between two pictures.

Follow the instructions below.

1. Student A: You have one picture. Student B: You have another picture. Do not show your picture to your partner! There are TEN differences between the pictures.

2. Look carefully at your picture. Think of how you can describe it to your partner.

3. Student A: Describe one thing about your picture and then ask your partner about her picture. E.g., There's one tree on a hill in my picture. Are there any trees in your picture?

4. Student B: Answer Student A's question and add some more information about your own picture. E.g., No, there aren't any trees in my picture, but there's a big house on the left. Have you got that?

5. Write down any differences you find or mark them on the picture. E.g., I have got a tree and you haven't, so that's one difference. The winner is the pair who can find all ten differences first.

\section{Student A picture}

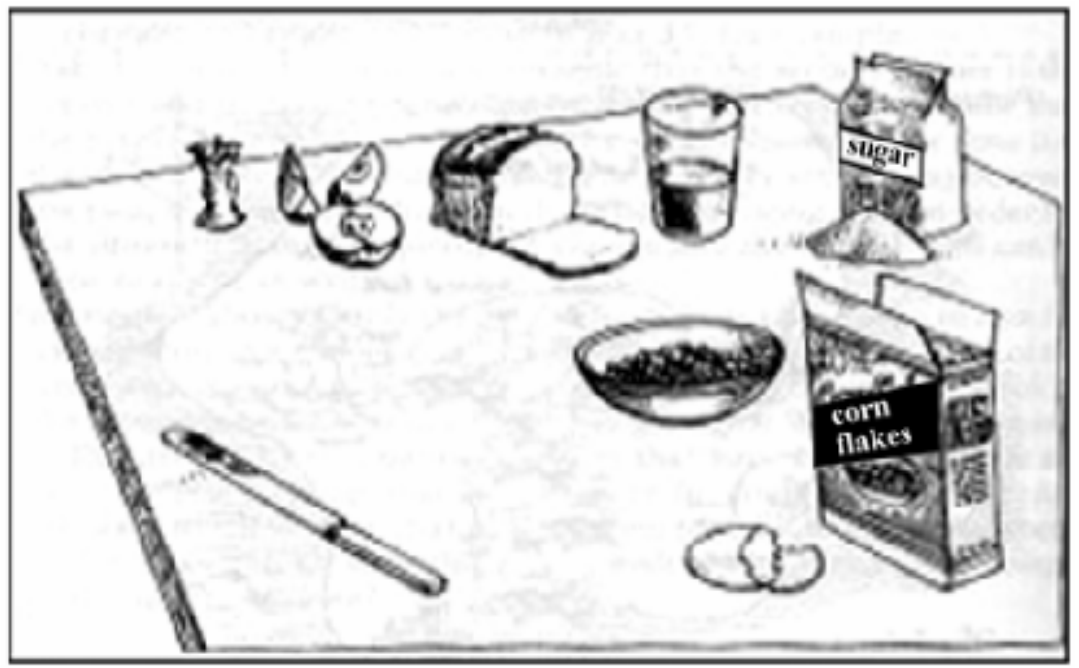

Student B picture

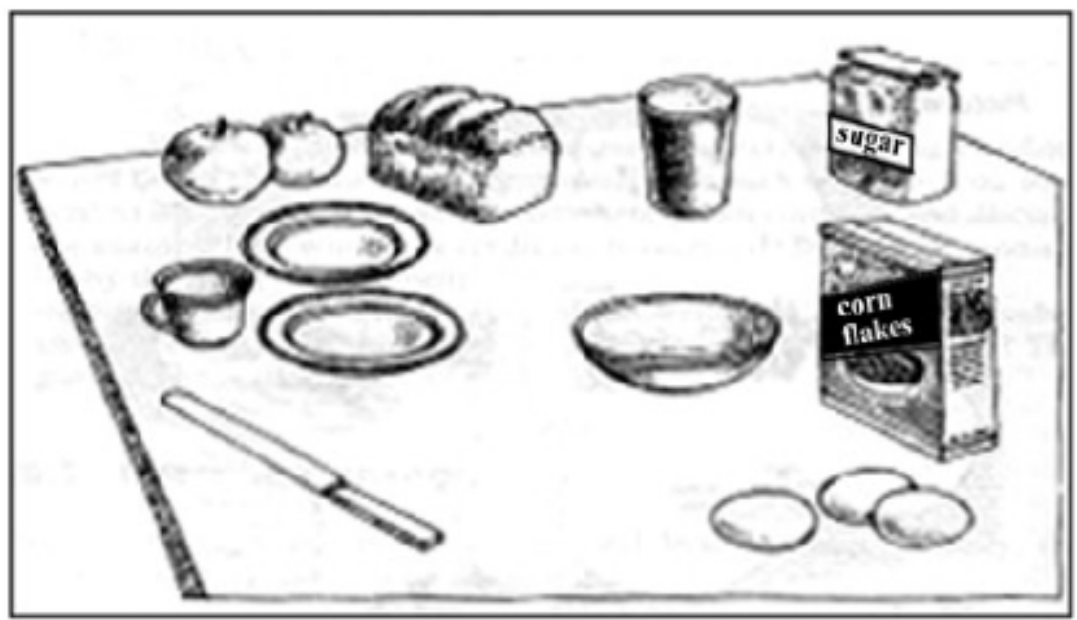

